\title{
ANALISIS KEBUTUHAN UNTUK PENINGKATAN USAHA PETERNAKAN SAPI PERAH DI KECAMATAN UNGARAN TIMUR KABUPATEN SEMARANG
}

\author{
T. Dalmiyatun, W. Roessali, W. Sumekar, D. Mardiningsih \\ Fakultas Peternakan dan Pertanian, Universitas Diponegoro \\ Kampus Tembalang Semarang 50275 Jawa Tengah \\ E-mail: tutik.dalmiyatun@undip.ac.id
}

\begin{abstract}
This research aimed to study the needs of members of farmers District East Ungaran Semarang Regency for the development of their farming. This research analyzed descriptively by using the approach of PRA (Participatory Rural Appraisal) approach, with the techniques of thematic mapping, trends and changes, seasonal calendar, daily routine, livelihood analysis and Venn Diagram on dairy farmers. Results from the application of each single technique then was discussed in Focused Group Discussion (FGD) attended by village officers and extension worker. The results of the study can be contained in rank as follows: 1) The activities carried out by members of dairy farmer groups is still traditional. Technologies of seed selection, feed, milking, harvest and post-harvest has not been much progress, yet, 2) Limited knowledge and access to sources of technology, resources, and capital and programs for both private and government 3) Limitation of production facilities and infrastructure, which resulted in small-scale livestock ownership with inadequate productivity, and 4) Limited mastery of market information, both for sale of the products and purchase of the production factors.
\end{abstract}

Keywords: Needs Assessment, development of farm enterprise

\begin{abstract}
Abstrak : Penelitian ini bertujuan untuk mempelajari kebutuhan anggota kelompok peternak di Kecamatan Ungaran Timur, Kabupaten Semarang untuk pengembangan peternakan sapi perah. Penelitian ini dianalisis secara deskriptif dengan menggunakan pendekatan PRA (Participatory Rural Appraisal), dengan teknik-teknik thematic mapping, trends and changes, seasonal calendar, daily routine, livelihood analysis dan Venn diagram pada peternak sapi perah. Hasil dari penerapan masing-masing teknikteknik tersebut kemudian didiskusikan dalam focussed group discussion (FGD) yang menghadirkan pengurus kelompok peternak, perangkat desa dan PPL kecamatan. Hasil dari kajian tersebut dapat dituangkan dalam susunan peringkat sebagai berikut: 1) Kegiatan yang dijalankan oleh anggota kelompok peternak sapi perah di kecamatan Ungaran Timur masih bersifat tradisional. Teknologi pemilihan bibit, pakan, pemerahan dan pascapanen belum banyak kemajuan, 2) Terbatasnya pengetahuan dan akses masyarakat terhadap sumber-sumber teknologi, sumber, modal dan dan program-program baik swasta maupun pemerintah, 3) Keterbatasan sarana dan prasarana produksi, yang mengakibatkan skala kepemilikan ternak yang kecil dengan produktivitas yang belum memadai dan 4) Terbatasnya penguasaan informasi pasar, baik untuk penjualan hasil maupun pembelian sarana produksi
\end{abstract}

Kata Kunci: kajian kebutuhan, pengembangan peternakan sapi perah

\section{PENDAHULUAN}

Peternakan merupakan subsektor pertanian dimana menjadi pemasok kebutuhan protein hewani bagi masyarakat. Salah satu usaha peternakan yang berkembang diantaranya yaitu peternakan sapi perah. Sapi perah merupakan golongan hewan ternak ruminansia yang dapat 
mendukung pemenuhan kebutuhan akan bahan pangan bergizi tinggi yaitu susu. Semakin tingginya kesadaran masyarakat akan pemenuhan gizi sehingga meningkatkan jumlah permintaan susu. Perkembangan ini senantiasa di dorong oleh pemerintah agar swasembada susu tercapai secepatnya.

Produktivitas susu segar sangat ditentukan oleh pengadaan faktor produksi (input). Faktor produksi usaha ternak sapi perah diantaranya bahan baku pakan baik pakan hijauan maupun konsentrat untuk pertumbuhan ternak, penyediaan kandang bagi ternak yang disesuaikan dengan daya tampung ternak, bibit ternak sapi perah dipilih yang memenuhi persyaratan tertentu. Inseminasi buatan untuk ternak sapi perah dipilih bibit yang unggul, pengadaan peralatan pemeraman serta pemeliharaan yang dapat memperlancar dalam proses pemerahan dan pemeliharaan ternak, serta tenaga kerja yang mempunyai pengetahuan dan ketrampilan mengenai usaha ternak sapi perah.

Dengan perkembangan globalisasi usaha peternakan dituntut mampu bertahan dan berkembang mengikuti perkembangan tersebut tetapi kendalanya usaha peternakan di Indonesia sebagian besar masih berskala kecil. Maka dari itu perlu mengetahui kebutuhan peternak untuk bisa mengembangkan usaha peternakan sapi perah. Kegiatan ini dilakukan dalam kaitannya dengan rintisan program pemberdayaan peternak di kabupaten Semarang. Pengkajian kebutuhan ini menggunakan metoda PRA, dalam rangka memenuhi prinsip-prinsip 'community empowering' yang meliputi prinsip edukasi, keberpihakan, partisipasi, transparansi dan akuntabilitas publik, keberlanjutan jangka panjang dan prinsip kesetaraan. Dalam kegiatan ini konsep pemberdayaan mengacu pada proses dimana orang memperoleh kontrol atas faktorfaktor dan keputusan yang membentuk kehidupan mereka. Ini adalah proses dimana mereka meningkatkan aset dan atribut mereka dan membangun kapasitas untuk mendapatkan akses, mitra, jaringan dan atau suara, dalam rangka untuk mendapatkan kontrol. Pemberdayaan juga mempunyai pengertian memampukan, mereka hanya bisa memberdayakan diri dengan adanya kontrol pada sumberdaya yang mempengaruhi hidup dan kehidupan mereka. Dengan demikian maka agen eksternal adalah untuk mengkatalisis, memfasilitasi atau memotivasi masyarakat dalam memperoleh kekuatan tersebut.

\section{METODOLOGI PENELITIAN}

Penelitian ini dilaksanakan bulan maret sampai april 2015, melibatkan responden peternak sapi perah diwilayah ungaran timur dengan jumlah 60 peternak, selain itu juga melibatkan perangkat desa dan petugas dinas peternakan kabupaten semarang. Penelitian ini dianalisis secara deskriptif dengan menggunakan pendekatan PRA (Participatory Rural Appraisal), yaitu metoda yang mendorong masyarakat pedesaan untuk berperan serta dalam menganalisis dan meningkatkan pengetahuan mereka tentang kondisi mereka sendiri sehingga dapat membuat perencanaan dan tindakan yang mempengaruhi hidup dan kehidupan mereka (Rianingsih, 1996). Prinsip dari PRA ini adalah dari, oleh dan untuk masyarakat, yang dapat dipertentangkan dengan pendekatan konvensional yang bersifat mengajari. Oleh sebab itu pelibatan masyarakat secara aktif dan bekerjasama merupakan hal yang utama dalam penyusunan kajian ini.

Ada banyak teknik dalam PRA yang sudah dikembangkan dan digunakan dalam pendekatan pemberdayaan masyarakat. Teknikteknik tersebut oleh Chambers (1993) dikatakan belum final, karena masih dapat dikembangkan dan dimungkinkan pula diciptakan teknik-teknik yang baru dan sesuai dengan kondisi setempat.

Dalam kajian ini teknik yang digunakan adalah:

1. Thematic Mapping, yaitu teknik PRA yang digunakan untuk memfasilitasi penyusunan peta desa tersebut beserta lingkungannya yang ada kaitannya dengan sumberdaya umum desa untuk peningkatan usaha peternakan sapi perah.

2. Trends and Changes, yaitu teknik pembuatan bagan kecenderungan dan dan perubahan yang dapat menggambarkan perubahan-perubahan berbagai keadaan, kejadian, serta kegiatan masyarakat dari waktu ke waktu, sehingga tergambarkan kecenderungan umum dalam kaitannya dengan usaha peternakan yang dapat bersifat berkurang, tetap, atau bertambah, dikaitkan dengan waktu lampau, sekarang dan di masa depan 
3. Daily Routine, yaitu teknik yang digunakan untuk mengkaji kegiatan yang dilakukan setiap hari pada setiap anggota keluarga.

4. Seasonal Calendar, yaitu teknik yang digunakan untuk mengkaji kegiatankegiatan dan keadaan-keadaan yang terjadi berulang dalam suatu kurun waktu tertentu, sehingga dapat digambarkan dalam system kalender (musiman). Informasi yang dicari dari teknik ini adalah ketersediaan pakan terutama pada musim paceklik, biaya pemeliharaan, dan produksi/produktivitas; ketersediaan tenaga kerja; musim bekerja ke kota atau tempat lain pada masa paceklik; masalah penyakit ternak; kesehatan (musim wabah penyakit) dan kebersihan lingkungan; pola pngeluaran (konsumsi, produksi, investasi); kegiatan sosial (kemasyarakatan), adat, agama; dan sebagainya.

5. Venn Diagram, merupakan teknik PRA yang sering dipergunakan untuk melihat hubungan berbagai lembaga yang terdapat di desa, sehingga diagram ini dikenal sebagai 'bagan hubungan kelembagaan'. Venn diagram digunakan untuk memfasilitasi kajian hubungan antara masyarakat dengan lembaga-lembaga yang terdapat di lingkungannya. Hasil pengkajian dituangkan ke dalam diagram Venn, berbentuk lingkaran-lingkaran yang jarak dan besarnya lingkaran menunjukkan besarnya potensi kemanfaatan, pengaruh dan dekatnya hubungan suatu lembaga dengan masyarakat.

6. Livelihood Analysis, yaitu teknik yang digunakan memfasilitasi diskusi mengenai berbagai aspek mata pencaharian masyarakat. jenis-jenis mata pencaharian beserta aspek-aspeknya digambarkan di dalam sebuah bagan. Informasi yang dikaji yaitu jenis-jenis kegiatan atau keterampilan masyarakat yang dapat atau telah menjadi sumber mata pencaharian, baik peternakan sapi perah maupun bukan peternakan sapi perah, ataupun bidang jasa.

\section{HASIL DAN PEMBAHASAN}

\section{Gambaran Umum Wilayah}

Kabupaten Semarang merupakan salah satu wilayah kabupaten di Jawa Tengah, merupakan daerah yang sangat potensial untuk pengembangan sapi perah rakyat. Letak wilayah Kabupaten Semarang berada di posisi 1100141 54,7511 sampai dengan 1100391 311 BT dan 70315711 sampai dengan 703011 LS, dengan ketinggian $318-1.450 \mathrm{~m}$ dpl. Luas wilayah Kabupaten Semarang 95.021 Ha, terdiri lahan sawah $4.418 \mathrm{Ha}(25,69 \%)$ dan non sawah $70.603 \mathrm{Ha}(74,31 \%)$. Suhu udara ratarata sebesar $26,2^{\circ} \mathrm{C}$, dan curah hujan sebanyak $2.064 \mathrm{~mm} /$ tahun.

Populasi ternak sapi perah tahun 2013 di Kabupaten Semarang berdasarkan Hasil Sensus Pertanian tahun 2013, sebanyak 22.308 Ekor. Kegiatan usaha beternak di daerah penelitian sangat penting, dikarenakan usaha tersebut digunakan sebagai fungsi pendukung pendapatan keluarga, sumber, bahan baku industri susu oleh Industri Pengolah Susu (IPS), bahan pangan bergizi tinggi, tabungan keluarga, penyerapan tenaga kerja. Berdasarkan produksi susu, pada tahun 2013, sebanyak 27.530.077 liter, tertinggi kedua setelah Kabupaten Boyolali (46.906.493). Produksi susu selama 5 tahun terakhir (2009-2013) di Kabupaten Semarang mengalami penurunan $1,35 \%$. Tingkat produksi susu selama 5 tahun (2009-2013) dapat dilihat pada Tabel 1.

Tabel 1. Produksi Susu di Kabupaten Semarang selama 5 Tahun 2009-2013

\begin{tabular}{lll}
\hline & Tahun & Produksi Susu (liter) \\
\hline 1 & 2009 & 30.039 .838 \\
2 & 2010 & 34.568 .345 \\
3 & 2011 & 34.761 .635 \\
4 & 2012 & 34.386 .871 \\
5 & 2013 & 27.530 .077 \\
\hline
\end{tabular}

Sumber : Statitistik Peternakan Provinsi Jawa Tengah (2014)

\section{Gambaran Kelompok Peternak \\ Tingkat Pendidikan Responden}

Tingkat pendidikan peternak dapat membantu dalam penerapan prinsip-prinsip teknologi dalam bidang peternakan. Adapun tingkat pendidikan responden dapat dilihat pada tabel 2 berikut ini. 
Tabel 2. Klasifikasi Responden Berdasarkan Tingkat Pendidikan

\begin{tabular}{cccc}
\hline No & $\begin{array}{c}\text { Tingkat } \\
\text { Pendidikan }\end{array}$ & $\begin{array}{c}\text { Jumlah } \\
\text { (Orang) }\end{array}$ & $\begin{array}{c}\text { Persentase } \\
(\boldsymbol{\%})\end{array}$ \\
\hline 1 & SD tidak lulus & 8 & 13,33 \\
2 & SD/Sederajat & 26 & 43,33 \\
3 & SMP/Sederajat & 16 & 26,67 \\
4 & SMA/Sederajat & 10 & 16,67 \\
\hline & Total & $\mathbf{6 0}$ & $\mathbf{1 0 0}$ \\
\hline
\end{tabular}

Sumber: Data Primer yang telah diolah. 2015

Berdasarkan tabel 2 diatas dapat dilihat bahwa sebagian besar peternak memiliki tingkat pendidikan formal setingkat SD yaitu sebanyak 26 orang dengan persentase tertinggi sebesar 43,33\%, dan tingkat pendidikan SD tidak lulus dengan persentase terendah yaitu sebesar 13,33\%. Berdasarkan hasil tersebut maka dapat dilihat bahwa tingkat pendidikan masih relatif rendah, menurut Lestraningsih dan Basuki (2006) yang menyatakan bahwa, tingkat pendidikan berpengaruh terhadap kemampuan peternak dalam penerapan teknologi, disamping itu tingkat pendidikan dapat digunakan sebagai tolak ukur terhadap kemapuan berfikir seseorang.

\section{Pengalaman Beternak}

Berikut adalah klasifikasi responden berdasarkan pengalaman beternak dapat dilihat pada tabel 3 .

Tabel 3. Klasifikasi Responden Berdasarkan Pengalaman Beternak

\begin{tabular}{cccc}
\hline No & $\begin{array}{c}\text { Lama } \\
\text { Beternak } \\
\text { (Tahun) }\end{array}$ & $\begin{array}{c}\text { Jumlah } \\
\text { (Orang) }\end{array}$ & $\begin{array}{c}\text { Persentase } \\
(\%)\end{array}$ \\
\hline 1 & $1-5$ & 10 & 16,67 \\
2 & $6-10$ & 18 & 30 \\
3 & $11-15$ & 20 & 33,33 \\
4 & $16-20$ & 8 & 13,33 \\
& $>20$ & 4 & 6,67 \\
& Total & $\mathbf{6 0}$ & $\mathbf{1 0 0}$ \\
\hline
\end{tabular}

Sumber: Data Primer yang telah diolah. 2015

Berdasarkan tabel 3 diatas, dapat dilihat bahwa masyarakat di Kecamatan Ungaran Timur telah lama menjadi peternak hal ini ditunjukkan oleh persentase tertinggi ada pada pengalaman beternak antara 11 - 15 tahun yaitu sebesar 33,33\%, sebanyak 20 orang. Hal ini menujukkan bahwa peternak yang terlibat pada usaha peternakan tersebut telah memiliki cukup pengalaman dan pengetahuan yang ditunjukkan dengan lamanya mereka menjadi peternak, menurut Mastuti dan Hidayat (2008) menyatakan bahwa, semakin lama beternak diharapkan pengetahuan yang didapat semakin banyak sehingga ketrampilan dalam menjalankan usaha peternakan semakin meningkat.

\section{Jumlah Kepemilikan Ternak}

Besar kecilnya jumlah ternak yang dimiliki mempengaruhi besar kecilnya waktu yang dicurahkan untuk usaha tersebut. Berikut adalah klasifikasi responden berdasarkan jumlah ternak yang mereka miliki dapat dilihat pada tabel 4.

Tabel 4. Klasifikasi Responden Berdasarkan Jumlah Kepemilikan Ternak

\begin{tabular}{|c|c|c|c|}
\hline No & $\begin{array}{l}\text { Jumlah } \\
\text { Kepemilikan } \\
\text { Ternak }\end{array}$ & Jumlah & Persentase \\
\hline 1 & $2-4$ & 14 & 23,33 \\
\hline 2 & $5-7$ & 42 & 70 \\
\hline \multirow[t]{2}{*}{3} & $8-10$ & 4 & 6,67 \\
\hline & Total & 60 & 100 \\
\hline
\end{tabular}

Sumber . Data Primer yang telah diolah. 2015

Berdasarkan tabel 4 diatas dapat diketahui bahwa tingkat kepemilikan ternak responden masih tegolong kecil, hal ini dapat dilihat bahwa 42 responden memiliki jumlah ternak antara $5-7$. Berdasarkan tingkat kepemilikan ternak sebagian besar peternak di kelompok tani ternak di kecamatan Ungaran Timur masih tergolong tradisional.

\section{Kajian Kebutuhan}

Dalam kajian kebutuhan, pengertian kebutuhan sering disamakan dengan masalah atau problema. Pengertiannya adalah antara keadaan yang ideal dengan kenyataan yang ada. Dengan tidak hadirnya kondisi yang ideal oleh para anggota kelompok peternak ini maka usaha peternakan sapi perah yang mereka lakukan tidak dapat berjalan dengan optimal. Namun demikian, dalam menjalankan usaha peternakan sapi perah tersebut, tidak semua orang menyadari atau tidak merasakan adanya kebutuhan tersebut karena sempitnya wawasan atau kurangnya acuan. Sebagai contoh, bila 
kenaikan bobot sapi seseorang adalah $02 \mathrm{~kg}$ per ekor per hari, sedangkan teman-temannya jugai rata-rata produksinya juga $0,2 \mathrm{~kg}$, maka kondisi ini tidak dirasakan sebagai masalah. Padahal pada perlakuan tertentu, sapi tersebut dapat dapat menghasilkan $0,5 \mathrm{~kg}$ per hari.

Salah satu kekuatan dari penerapan PRA untuk mengkaji kebutuhan ini, teknik-teknik yang digunakan dapat membuka wawasan para peserta.

Berikut ini hasil kajian masing-masing teknik:

\section{Thematic mapping}

Dengan penerapan teknik ini, dapat diketahui bahwa wilayah Kabupaten Semarang memang mempunyai potensi yang sangat besar dalam bidang peternakan dan pertanian. Dukungan iklim dan kondisi memungkinkan peningkatan dan diversifikasi produksi pertanian. Sayangnya masyarakat kecamatan Ungaran Timur belum banyak memanfaatkan situasi ini. Perannya dalam agribisnis ini baru sebatas on-farm, sebagai peternak penghasil komoditas peternakan. Pekerjaan-pekerjaan off-farm belum mampu mereka kerjakan, padahal pekerjaan-pekerjaan inilah yang mendatangkan margin yang lebih besar.

2. Trends and changes

Dengan tema peningkatan usaha peternakan, teknik ini menemukan beberapa masalah antara lain semakin mahalnya harga bibit ternak, keterbatasan ketersediaan pakan, ketersediaan obat yang cocok untuk penyakit ternak sapi, kontinuitas kualitas hasil pemerahan susu, terdapat masalah juga mengenai rendahnya harga yang ditawarkan oleh KUD susu.

\section{Livelihood Analysis}

Dengan kajian teknik ini, didapatkan bahwa hampir keseluruhan peternak di kecamatan ungaran timur ini mempunyai pekerjaan yang terkait dengan pertanian, Keterbatasan penguasaan manajemen pengelolaan menyebabkan penghasilan dari pekerjaan peternakan tidak dapat mencukupi kebutuhan rumahtangga. Oleh sebab itu banyak penduduk yang bekerja di luar pertanian yang mereka sebut sebagai glidik atau bekerja serabutan.

\section{Daily Routine}

Dalam kesehariannya, masyarakat peternakan sapi perah menjalankan kegiatan pemeliharaan dan melakukan pemerahan, untuk pemerahan dilakukan 2 kali dalam 1 hari yaitu pagi dan sore hari. Terdapat pembagian kerja berdasarkan gender pada kegiatan-kegiatan tersebut, dimana laki-laki lebih berperan pada pencarian pakan sedangkan perempuan pada pemeliharaan. Saat pemberian pakan dapat dilakukan oleh laki-laki maupun perempuan. Tanggung jawab pekerjaan domestic ada pada pihak perempuan, sedangkan laki-laki sifatnya hanya membantu saja untuk pekerjaan domestic ini.

\section{Seasonal Calendar}

Peternak sapi perah di kecamatan ungaran timur bisa dikatakan sudah maju dibandingkan dengan jaman dahulu. Saat ini peternak kita sudah mengenal adanya kawin suntik (Inseminasi Buatan/IB). Cara ini ternyata lebih efektif dibandingkan dengan kawin alam dalam usaha untuk menjaga kontinyuitas produksi susu. Biaya per suntik juga masih terjangkau oleh peternak rakyat. Saat ini sekali suntik IB membutuhkan biaya sekitar Rp. 35.000,sampai Rp. 40.000,-. Jika kita dapat mengatur IB dengan tepat, maka produksi susu lebih baik, dan hal ini tentunya akan menjamin pendapatan yang diterima peternak. Sebelum melakukan IB, tentunya ada hal penting yang harus diperhatikan dengan baik, yakni melakukan deteksi birahi. Jika IB tidak dilakukan setelah birahi atau pada waktu yang tepat, tentunya IB-nya tidak akan berhasil. Hal yang dilakukan untuk memudahkan melakukan deteksi birahi dan kemudahan dalam manajemen reproduksi sapi perah, maka diperlukan adanya kalender reproduksi. Kalender reproduksi merupakan bagan yang terdiri dari kotak-kotak dimana jumlah tiap barisnya sebanyak 21 kotak. Sapi normal birahi setiap 20 sampai 21 hari sekali. Kalender reproduksi disini digunakan untuk mencatat tanggal birahi atau tanggal IB sebelumnya serta memperkirakan tanggal birahi berikutnya. Jika kita amati pada kalender reproduksi, kotak melambangkan hari dan setiap kotak untuk 
1 hari. Satu baris dari kotak kalender reproduksi terdiri dari 21 kotak. Kotak baris ke-1 dengan baris berikutnya selisihnya 21 hari.

6. Venn Diagram

Selama ini Peternak sapi perah di kecamatan ungaran timur dapat dikatakan bekerja sendiri, akses pada sumber teknologi, edukasi maupun modal masih sangat terbatas. Adapun lembaga yang melakukan kerjasama dengan peternak di wilayah kecamatan Ungaran Timur adalah KUD. Dimana biasanya para peternak melakukan pemasaran hasil susu segarnya ke KUD tersebut. Sumber-sumber teknologi misalnya dari BPPT, Dinas Pertanian, Dinas Peternakan dan Perikanan masih sangat terbatas, balai-balai pertanian belum pernah mereka akses.

\section{KESIMPULAN}

Dari kajian yang dilakukan dengan keenam teknik tersebut, kemudian dapat dibuat ranking, yang menggambarkan peringkat permasalahan yang ditemukan dalam penerapan teknik sebelumnya. Peringkat permasalahan tersebut adalah sebagai berikut:

1. Kegiatan yang dijalankan oleh anggota peternak sapi perah di Kecamatan Ungaran Timur masih bersifat tradisional.

2. Terbatasnya pengetahuan dan akses masyarakat terhadap sumber-sumber teknologi, sumber, modal dan dan program-program baik swasta maupun pemerintah

3. Keterbatasan sarana dan prasarana produksi, yang mengakibatkan skala kepemilikan ternak yang kecil dengan produktivitas yang belum memadai

4. Terbatasnya penguasaan informasi pasar, baik untuk penjualan hasil maupun pembelian sarana produksi
Dengan permasalahan tersebut, tahapan program pemberdayaan dapat dilanjutkan yaitu dengan membuat perencanaan bersama, dengan memilih kegiatan yang kemanfaatannya besar, yang sesuai denganpotensi yang dimiliki dengan membuka akses pada sumber-ipteks dan permodalan.

\section{SARAN}

Perlu dilakukan analisis SWOT agar lebih detail mengetahui strategi pengembangan peternakan sapi perah yang paling efektif.

\section{DAFTAR PUSTAKA}

Chambers, R. 1993. Rural Development, Putting the Last First, Essex, England: Longmans Scientific and Technical Publishers; New York: John Wiley

Dinas Peternakan Propinsi Jawa Tengah. 2014 Buku Statistik Peternakan Tahun 2014. Tarubudaya, Ungaran.

Lestraningsih, M dan Basuki, E. 2008. Peran Serta Wanita Peternak Sapi Perah Dalam Meningkatkan Taraf Hidup Keluarga. Jurnal Ekuitas Vol.12 No.1, Maret 2008. Sekolah Tinggi Ilmu Ekonomi Indonesia (STIESIA) Surabaya.

Mastuti dan Hidayat. 2008. Peranan Tenaga Kerja Perempuan dalam Usaha Ternak Sapi Perah di Kabupaten Banyumas (Role of Women Workers at Dairy Farms in Banyumas District) Fakultas Peternakan Universitas Jenderal Soedirman, Purwokerto.

Rianingsih, D. 1996. Berbuat Bersama Berperan Setara. Driya Media. Bandung. 